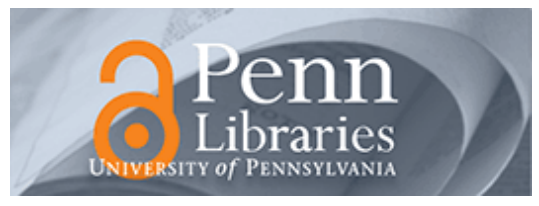

University of Pennsylvania

ScholarlyCommons

Finance Papers

Wharton Faculty Research

$10-2015$

\title{
Demand for fixed-price multi-year contracts: Experimental evidence from insurance decisions
}

Howard Kunreuther

University of Pennsylvania

Erwann Michel-Kerjan

University of Pennsylvania

Follow this and additional works at: https://repository.upenn.edu/fnce_papers

Part of the Finance and Financial Management Commons, and the Insurance Commons

\section{Recommended Citation}

Kunreuther, H., \& Michel-Kerjan, E. (2015). Demand for fixed-price multi-year contracts: Experimental evidence from insurance decisions. Journal of Risk and Uncertainty, 51 (2), 171-194. http://dx.doi.org/ 10.1007\%2Fs11166-015-9225-4

This paper is posted at ScholarlyCommons. https://repository.upenn.edu/fnce_papers/97

For more information, please contact repository@pobox.upenn.edu. 


\title{
Demand for fixed-price multi-year contracts: Experimental evidence from insurance decisions
}

\begin{abstract}
Do individuals prefer a fixed-price multi-year insurance (MYI) policy to current annual contracts with fluctuating prices? If so, are they willing to pay more for these policies? In a web-based 2-period repeated game with significant real money at stake, individuals have an opportunity to purchase 1-period insurance contracts, 2-period contracts or no insurance against the risk of a hurricane causing damage to their property. When premiums for both insurance options are actuarially fair, more than five times as many people favor the 2-period contract over the 1-period contract. The demand for a 2-period contract remains high even with a loading cost of $5 \%$ and $10 \%$ while keeping the 1-period premium actuarially fair, indicating a preference for stable premiums over time. These findings support the need for multi-year contracts that will lead more individuals to be adequately protected against future extreme events, given the empirical evidence on lack of interest in insurance against catastrophic risks.
\end{abstract}

\section{Keywords}

Individual decision-making, choice under uncertainty, multi-year insurance, disaster

\section{Disciplines}

Business | Finance and Financial Management | Insurance 


\section{Demand for Fixed-Price Multi-Year Contracts: Experimental Evidence from Insurance Decisions}

\author{
Howard Kunreuther \\ The Wharton School \\ University of Pennsylvania
}

\section{Erwann Michel-Kerjan}

The Wharton School

University of Pennsylvania

January 2015

Working Paper \# 2015-04

Risk Management and Decision Processes Center

The Wharton School, University of Pennsylvania

3730 Walnut Street, Jon Huntsman Hall, Suite 500

Philadelphia, PA, 19104

USA

Phone: 215-898-5688

Fax: 215-573-2130

http://opim.wharton.upenn.edu/risk/ 


\section{THE WHARTON RISK MANAGEMENT AND DECISION PROCESSES CENTER}

Established in 1984, the Wharton Risk Management and Decision Processes Center develops and promotes effective corporate and public policies for low-probability events with potentially catastrophic consequences through the integration of risk assessment, and risk perception with risk management strategies. Natural disasters, technological hazards, and national and international security issues (e.g., terrorism risk insurance markets, protection of critical infrastructure, global security) are among the extreme events that are the focus of the Center's research.

The Risk Center's neutrality allows it to undertake large-scale projects in conjunction with other researchers and organizations in the public and private sectors. Building on the disciplines of economics, decision sciences, finance, insurance, marketing and psychology, the Center supports and undertakes field and experimental studies of risk and uncertainty to better understand how individuals and organizations make choices under conditions of risk and uncertainty. Risk Center research also investigates the effectiveness of strategies such as risk communication, information sharing, incentive systems, insurance, regulation and public-private collaborations at a national and international scale. From these findings, the Wharton Risk Center's research team - over 50 faculty, fellows and doctoral students - is able to design new approaches to enable individuals and organizations to make better decisions regarding risk under various regulatory and market conditions.

The Center is also concerned with training leading decision makers. It actively engages multiple viewpoints, including top-level representatives from industry, government, international organizations, interest groups and academics through its research and policy publications, and through sponsored seminars, roundtables and forums.

More information is available at http://www.wharton.upenn.edu/riskcenter 


\title{
Demand for Fixed-Price Multi-Year Contracts: Experimental Evidence from Insurance Decisions
}

\author{
Howard Kunreuther and Erwann Michel-Kerjan ${ }^{1}$
}

January 20, 2015

\begin{abstract}
Do individuals prefer a fixed-price multi-year insurance (MYI) policy to current annual contracts with fluctuating prices? If so, are they willing to pay more for these policies? In a web-based 2-period repeated game with significant real money at stake, individuals have an opportunity to purchase 1-period insurance contracts, 2-period contracts or no insurance against the risk of a hurricane causing damage to their property. When premiums for both insurance options are actuarially fair, more than five times as many people favor the 2-period contract over the 1-period contract. The demand for a 2-period contract remains high even with a loading cost of 5\% and 10\% while keeping the 1-period premium actuarially fair, indicating a preference for stable premiums over time. These findings support the need for multi-year contracts that will lead more individuals to be adequately protected against future extreme events, given the empirical evidence on lack of interest in insurance against catastrophic risks.
\end{abstract}

Key words: individual decision-making; choice under uncertainty; multi-year insurance; disaster

JEL: C90, D81; G22

\footnotetext{
${ }^{1}$ H. Kunreuther, Center for Risk Management and Decision Processes, The Wharton School, University of Pennsylvania, Huntsman Hall, Suite 500, 3730 Walnut Street, Philadelphia, PA, 19104, USA, e-mail: kunreuth@wharton.upenn.edu

E. Michel-Kerjan, Center for Risk Management and Decision Processes, The Wharton School, University of Pennsylvania, Huntsman Hall, Suite 500, 3730 Walnut Street, Philadelphia, PA, 19104, USA e-mail:erwannmk@wharton.upenn.edu.
}

Our appreciation to Barbara Klimaszewski-Blettner who collaborated with us on designing the experiments and Kenneth Reisman who implemented the computer program. Special thanks to Jeff Cai and Krishna Kaliannan who provided excellent research assistance and to Carol Heller for her editorial assistance. Wouter Botzen, Jingqiu Chen, Glenn Harrison, David Krantz, Robert Meyer, Haitao Yin and participants in seminars at Wharton and Georgia State provided us with insightful comments on an earlier draft of the paper. We also thank the reviewers and Kip Viscusi for very helpful feedback on earlier versions of the paper. Support for this research comes from the National Science Foundation (SES-1061882 and SES-1062039); the Center for Climate and Energy Decision Making through a cooperative agreement between the National Science Foundation and Carnegie Mellon University (SES-0949710); the Center for Risk and Economic Analysis of Terrorism Events (CREATE) at the University of Southern California; the Center for Research on Environmental Decisions (CRED; NSF Cooperative Agreement SES-0345840 to Columbia University), the Zurich Insurance Foundation and the Wharton Risk Management and Decision Processes Center. 


\section{Introduction}

Researchers interested in risk and uncertainty have been aware of the limited interest by consumers in purchasing insurance and investing in protection against extreme events. While the number and cost of natural disasters have been increasing steadily, studies reveal that many homeowners do not have adequate coverage against floods, hurricanes and earthquakes (Kunreuther et al., 1978; Michel-Kerjan, 2010; Kousky and Cooke, 2012; Botzen. and van den Bergh, 2012; Friedl, Lima de Miranda and Schmidt, 2014).

To illustrate this point in the context of hurricane losses in the United States, the U.S. Department of Housing and Urban Development revealed that $41 \%$ of homes damaged by Hurricanes Katrina, Rita and Wilma in 2005, were uninsured or underinsured. Of the 60,196 owner-occupied homes with severe wind damage from these hurricanes, 23,000 did not have insurance against wind loss (U.S. Government Accountability Office, 2007). Kriesel and Landry (2004) and Dixon et al. (2006) found that only about half of the homes in high-risk areas had flood insurance. Along the entire New York coast affected by Hurricane Sandy in 2012, the City of New York found that $80 \%$ of residents in the inundated area did not have flood insurance, despite that coverage being subsidized for many (City of New York, 2013). We discuss research in the economics and behavioral literature that provide explanations for this behavior in the body of the paper.

One contractual arrangement that has not been given much attention is the marketing of property insurance as an annual policy in most countries around the world. ${ }^{2}$ Following natural disasters, such as major hurricanes, floods and earthquakes, premiums often increase significantly and policies may be canceled by insurers. After the 2004 and 2005 hurricane seasons many insurers did not renew coverage for a number of homeowners in coastal regions of the United States (Klein, 2007). While most of these residents were able to find coverage

\footnotetext{
${ }^{2}$ Although multi-year insurance policies to cover property damage have not yet been implemented in the United States, Mooney (2001) reports that in several Asian countries, homeowners' policies are written for terms longer than one year. In some cases, the policy is written for the life of the mortgage. In this case the premium is discounted and paid up front as an incremental cost to the mortgage. There are anecdotes of multi-year homeowners' insurance policies also sold in Germany but to the best of our knowledge there has been no published studies on these contracts.
} 
with other insurers, their new contracts typically were more expensive and had a higher deductible and a lower maximum compensation limit than their previous policies (Vitelo, 2007). The average homeowner's premium in the state of Florida increased from \$723 in 2002 to $\$ 1,465$ in 2007. In coastal areas, some insurers were permitted by regulators to triple or even quadruple their premiums for some homeowners after 2005 (Kunreuther and Michel-Kerjan, 2011). ${ }^{3}$ Those who could not obtain coverage from the private market had to purchase coverage from state insurance pools, which play the role of insurers of last resort. (Grace and Klein, 2009).

Residents in hazard-prone areas often question why insurance companies, viewed as experts in risk assessment, increase their rates so dramatically following a disaster. Those in harm's way believe pre-disaster premiums reflected the likelihood of claims arising from extreme events, so they should not change after an event occurs. Many residents are also concerned as to whether coverage will be available against these risks from their insurer in the future, and for good reason. Following Hurricane Andrew that caused severe damage to property in Miami-Dade County, Florida in 1992, insurers threatened to discontinue homeowners' policies in Florida. To prevent this from happening, the state legislature enacted a bill that prohibited individual insurance firms from canceling more than $10 \%$ of their homeowners policies in any Florida county in any one year, and more than 5\% of their policies' statewide between 1993 and 1996 (Lecomte and Gahagan, 1998).

To address the above concerns by property owners we introduce a fixed-price multi-year insurance (MYI) contract and examine its demand relative to standard annual contracts in a field experiment. Multi-year insurance offers several advantages over single year policies. For the insured, the focus of this paper, MYI would offer stable premiums over time rather than having them significantly increase after a disaster, thus providing homeowners with more certainty

\footnotetext{
${ }^{3}$ This was partly due to higher reinsurance prices covering catastrophe losses and the upward revision of risk by catastrophe modelers to reflect changes in their estimates of the likelihood and consequences of future disasters. For example, following Hurricane Katrina in 2005, the price of catastrophe risk reinsurance for Florida-based insurers more than doubled. Moreover, there was an upward revision in the likelihood and consequences of damage from hurricanes by the three leading modeling companies - AIR Worldwide, EQECAT and Risk Management Solutions (Kunreuther and Michel-Kerjan, 2011).
} 
regarding their budgetary planning process. ${ }^{4}$ Multi-year contracts would also have important societal benefits by limiting the number of residents in hazard prone areas who cancel their insurance after only a short period of time, behavior that has been documented empirically (Michel-Kerjan, Lemoynes de Forges and Kunreuther, 2012). When they suffer losses from a disaster these victims request federal relief because they are unprotected. The political debate around the $\$ 50$ billion post-Hurricane Sandy relief in 2012 demonstrates the importance of developing strategies for increasing personal responsibility by those in harm's way. MYI has the potential of doing this.

There is precedence for multi-year contracts in the life insurance arena. Term-life policies are typically offered with premiums "locked in" for five to ten years; buyers can choose whether they want to pay extra for such guarantees over annual contracts knowing that they may drop coverage at any time. Policyholders are then certain what their life insurance premiums will be over the next five or ten years, regardless of what happens to their health or the overall mortality rate of their insurer's portfolio.

Hendel and Lizzeri (2003) examine 150 term-life insurance contracts, some of which have fixed premiums for 5, 10 or 20 years while others are 1-year renewable policies. They show that on average, the extra prepayment of premiums to protect consumers against being reclassified into a higher risk category for a fixed period of time is more costly over the total period of coverage than a series of one-year term policies that can be renewed but where premiums may fluctuate from year to year. Still, people buy these multi-year fixed-price life insurance policies, indicating that they view the stability of premiums as an important attribute and are willing to pay extra for a guaranteed price.

To date there has been no empirical analysis on the demand for multi-year property coverage except for Papon (2008) who undertook a lab experiment with 64 undergraduate students from the University of LeMans in France with subject being divided into two groups: one group was given the option of purchasing a single period insurance policy and the other presented with a policy that covered them for four periods in a row. Papon found that the demand for insurance was significantly higher for those who could purchase a multi-period contract

\footnotetext{
${ }^{4}$ From the insurer's perspective it would reduce the variance with respect to claims payments by diversifying its portfolio over the number of policyholders and over time. It would also reduce marketing and other administrative costs that an insurer has to incur in renewing one-year contracts.
} 
relative to those who were offered a single period insurance policy, attributing this effect to the longer period of commitment.

This paper builds on this research by developing a multi-period field experiment with single and multi-period insurance contracts that cannot be cancelled. Participants are presented with the following options with large amounts of real money at stake: no insurance, 1-period insurance, 2-period insurance. Our goal is to determine the extent to which individuals have an interest in purchasing multi-period coverage against losses from a disaster that occur with a relatively low probability and to understand the factors that influence their insurance decisions. While commitment is an important aspect, other elements also play an important role in explaining the significant demand for the fixed-price multi-period contracts, even when they cost more in total than single-period policies priced at an actuarially fair rate. We are also interested in whether risk attitudes, and socio-economic characteristics such as age, gender and income impact on the insurance purchase decision for either type of contract.

We find that demand for a fixed-price 2-period insurance policy is five times greater than a 1-period contract where the premium can increase in period 2 should a disaster occur in period 1. We also find that individuals are ready to pay more for a two-period fixed priced contract than for a potentially variable one-period contract. We call this a premium for price stability.

Our findings also reveal that the overall demand for insurance (i.e., the combined demand for 1-period and 2-period contracts) increases when both types of contracts are offered rather than when just 1-period policies are available. Finally, those who are more risk averse are more likely to purchase 2-period rather than 1-period policies. Although we focus on the demand for disaster insurance our findings should have important implications for the design of other multi-year contracts outside of the insurance domain.

The paper is organized as follows. Section 1 provides a simplified model for determining the premiums that an insurer would charge if it were offering 1- and/or 2-period contracts in a competitive market with free entry and exit. Section 2 describes the web-based experiment where participants can decide to be uninsured or purchase 1- or 2-period insurance when they face significant losses from a hurricane that occurs with a well-specified probability. The amounts of money at stake were in the hundreds of dollars and the winners were selected randomly on the basis of games from the Pennsylvania Lottery to assure full transparency. Section 3 introduces testable hypotheses that are examined in Section 4 using data from 445 
adult individuals who participated in the experiment. Section 5 discusses the implications of these findings for marketing insurance and for designing public policy.

\section{A Two-Period Insurance Decision Model under Uncertainty}

We consider the case where identical homeowners have to decide whether to purchase insurance for two consecutive periods against a major hurricane that can severely damage their house. They have the option of not purchasing insurance (i.e., self-insuring), buying a 1-period contract in either period 1 and/or period 2, or purchasing a fixed-price 2-period contract for full coverage (i.e., no deductible) against the potential losses in periods 1 and/or 2 . If an individual purchases a 2-period insurance contract at the beginning of period $1, \mathrm{~s} /$ he cannot cancel it and thus remains protected for both periods.

At the beginning of period 1, outside experts (e.g., the National Weather Service in the U.S.) provide an estimate of the probability of a hurricane occurring in period 1 but are uncertain as to whether they will update this estimate for period 2. If no disaster has occurred in period 1, experts assume that their forecast model of hurricanes is correct and estimate the same probability in period 2 as in period 1. But if a hurricane occurred in period 1, experts update their probability estimate of a hurricane in period 2 by assuming it is higher than in period 1. This process is consistent with how the real disaster insurance market has operated in the aftermath of many weather-related risks in recent years. It might seems strange that experts update their estimate in this manner, but this is exactly what happened after the 2004 and 2005 hurricane season in the United States when catastrophe modelers increased their forecast of future hurricane in the short term by as much as 100\% (Kunreuther and Michel-Kerjan, 2011).

\section{Notation}

$\mathrm{Z}_{1}=$ insurance premium in period 1 for a 1-period policy, determined at the beginning of period 1

$\mathrm{Z}_{2}=$ insurance premium in period 2 for a 1-period policy, determined at the beginning of period 2

$\mathrm{Z}(\mathrm{MYI})=$ fixed insurance premium per period for MYI coverage determined at the beginning of period 1

$\mathrm{D}=$ insured damage if a disaster occurs

$\mathrm{p}=$ probability of a disaster $\mathrm{D}$ in period 1 
$\mathrm{p}=$ probability of a disaster $\mathrm{D}$ in period 2 if no hurricane occurs in period 1

$\mathrm{p}_{2 \mathrm{H}}=$ higher probability of a disaster $\mathrm{D}$ in period 2 if a hurricane occurs in period 1

$\mathrm{a}=$ weight placed by experts in period 1 on the likelihood of $\mathrm{p}$ in period 2 . We therefore assume that $\mathrm{p}_{2}=\mathrm{a} \mathrm{p}+(1-\mathrm{a}) \mathrm{p}_{2 \mathrm{H}}$

Based on the above notation we can determine the actuarially fair premiums charged by insurers for 1-period policies:

$$
\begin{aligned}
& Z_{1}=p D \\
& Z_{2}=p D \text { with likelihood } a \\
& Z_{2 H}=p_{2 H} D \text { with likelihood }(1-a)
\end{aligned}
$$

For fixed price 2-period contracts the premium charged by the insurer for each period is:

$$
\mathrm{Z}(2 \text {-period })=1 / 2(1+\lambda)\left\{\left[(1+\mathrm{a}) \mathrm{pD}+(1-\mathrm{a}) \mathrm{p}_{2 \mathrm{H}} \mathrm{D}\right]\right\}
$$

where $\lambda$ is a loading factor to reflect the cost of holding liquid capital to cover catastrophic losses should a disaster occur in both periods 1 and 2. This loading can also compensate the insurer for the uncertainty about the possible change in the probability of suffering a loss in period 2. If $\lambda=0$ then the insurance premium for the 2 period contract is actuarially fair.

\section{Experimental Design}

\subsection{Stimulus}

To determine the demand for single-period and multi-period insurance contracts we undertook an experiment with adults in the United States, most of whom were older than 30 so were likely to have experience purchasing insurance. The experiment consisted of 30 consecutive games, each game comprising two periods. The occurrence of a disaster in period 1 increases the estimated probability of a similar disaster in period 2, as explained above. At the end of period 1 , insurers use this information to update their probability estimates and recalculate the premiums they will charge for a single-period contract in period 2.

Participants in the experiment were asked to imagine that they owned a house for two periods and wanted to sell it at the end of period 2. At the beginning of period 1 the house is worth 100,000 talers (a fictitious currency where 1,000 talers= US\$5). A subject's total initial 
assets are the value of the house plus 5,000 talers in cash that $\mathrm{s} /$ he receives at the beginning of period 1. Appendix 2 provides the description of the instructions given to participants.

There is a chance that a major hurricane will occur in one or both periods. If such a hurricane occurs, the house will suffer a loss in value of 50,000 talers unless the subject has purchased insurance for that period, in which case s/he will be fully reimbursed by the insurer for the loss. The subject's house will then be immediately rebuilt and retains its original value of 100,000 talers at the beginning of the next period. If s/he has not purchased insurance and a hurricane occurs during the period, the value of the house will decrease by 50,000 talers. The amount of the participant's virtual bank account at the end of period 2 will be the value of the house at the end of period 2 plus 5,000 talers received at the beginning of the game, minus any insurance premiums paid in any of the two periods.

Subjects are told that experts estimate the likelihood of a hurricane occurring in period 1 to be 1 in 25 (i.e., $p=4 \%$ ). This probability is consistent with estimates for a specific city located on the Atlantic coast of the United States. If no hurricane occurs in period 1, subjects know that experts still estimate the chances of a hurricane striking in period 2 at $p=4 \%$. Subjects are told that if a hurricane occurs in period 1, experts will then revise their hurricane estimate upwards by $25 \%$ for period 2 so it is now $\mathrm{p}_{2 \mathrm{H}}=1$ in 20 (i.e., $\mathrm{p}=5 \%$ ) and the insurance cost will increase to reflect this higher risk. The loss probability is explicitly stated and is common knowledge.

If a decision was made by the subjects in the experiments to purchase 2-period insurance at the beginning of period 1 , then the participants do not make another decision at the beginning of period 2. If no insurance or a 1-period contract has been purchased at the beginning of period 1, the subject will have to make another decision as to whether s/he wants to buy a 1-period insurance policy at the beginning of period 2. After making their decision for period 1, subjects are shown on their computer screen whether a hurricane occurred in period 1 and the amount in their virtual bank account. They receive similar information at the end of period 2 . We used random numbers from a computer program to determine whether a hurricane occurred with a $4 \%$ chance for the first period and a $4 \%$ chance in the second period if no disaster occurred in period 1. If a hurricane occurred in period 1 the likelihood of another hurricane in period 2 is updated to $5 \%$. In the instructions to the participants in the experiment we indicate "the computer will determine the occurrence of a hurricane using a random number generator" so they know is this done in a neutral fashion. 
After the initial 2-period game is played, a new 2-period game begins with exactly the same rules. Subjects play 30 independent such 2-period games in a row to obtain a large number of responses. To avoid income effects, there is no accumulation of wealth across games. Repeating the same game also allows us to determine how demand for 1-period and 2-period insurance contracts evolves over time and whether it changes following the occurrence of a hurricane. We intentionally focused on a 2-period model to keep the experimental design simple. A graphical representation of this timeline is provided in Figure 1.

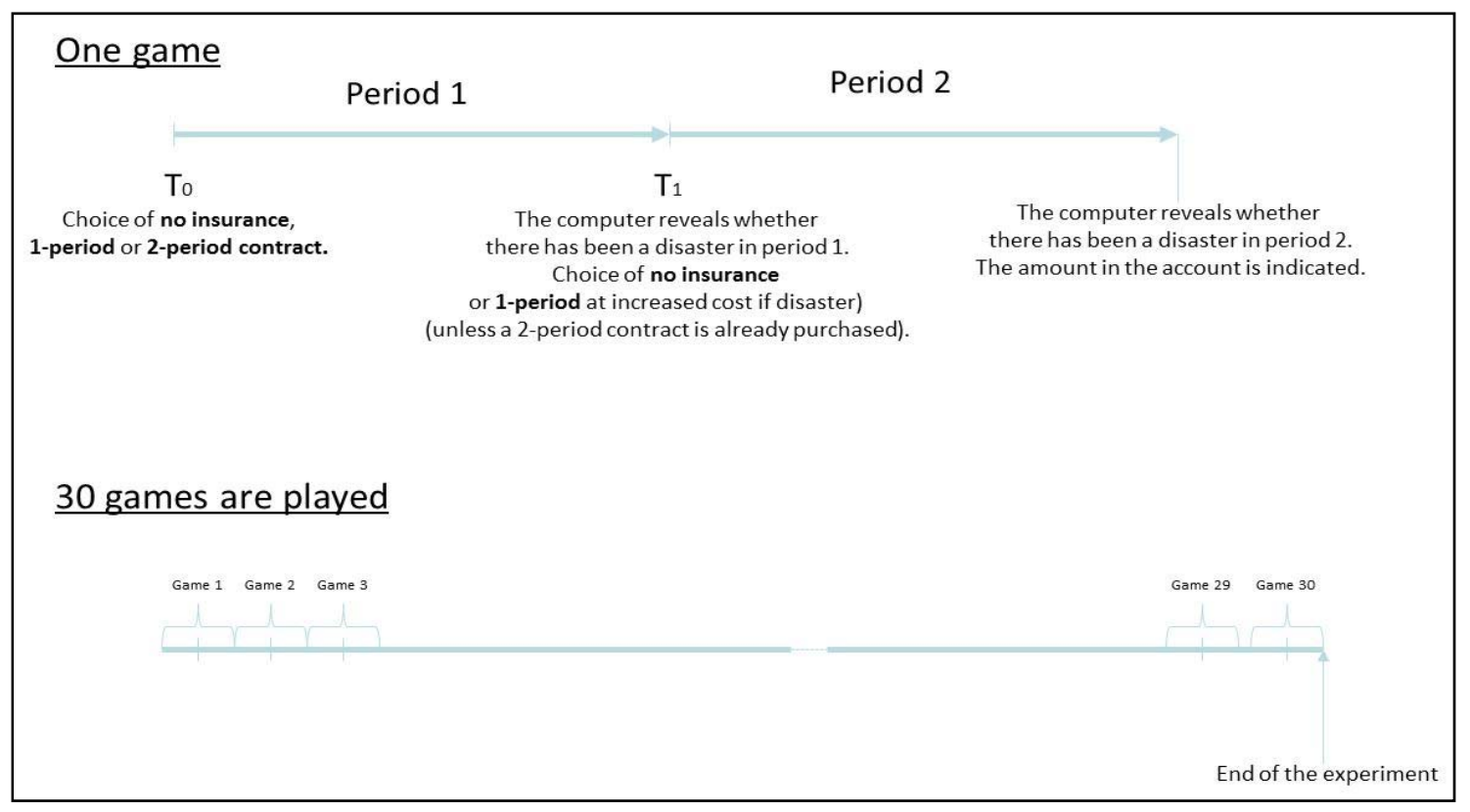

Fig. 1 Graphical Representation of the Experiment

The following treatments were investigated.

Treatment 1: Subjects are offered only 1-period contracts at actuarially fair prices given by equations (1a), (1b) and (1c). The participant only needs to decide whether or not to buy 1 period insurance. The premiums in period 1 and period 2 for single-period policies were determined by the expected loss defined in those equations (1a), (1b) and (1c) in Section 2. A premium of 2,000 talers $(1 / 25 * 50,000)$ was charged for insurance in period 1 , and 2,500 talers $(1 / 20 * 50,000)$ or 2,000 talers $(1 / 25 * 50,000)$ in period 2 depending on whether a hurricane did or did not occur in period 1.

Treatment 2: Subjects are offered 1- and 2-period insurance contracts at actuarially fair prices. Based on the above information for the 1-period policy, the 2-period contract premium in treatment 2 is the weighted average of these numbers [i.e., Z(MYI) as defined by equation (2), with $\lambda=0]$ : 


$$
\begin{aligned}
& \mathrm{Z}(2 \text {-period })=1 / 2\left\{\mathrm{pD}(1+\mathrm{a})+(1-\mathrm{a}) \mathrm{p}_{2 \mathrm{H}} \mathrm{D}\right\} \\
& \mathrm{Z}(2 \text {-period })=0.5 .\{1.96(2,000)+0.04(2,500)\}=2,010
\end{aligned}
$$

More specifically, the actuarially fair premium for the 2-period contract reflects the decision by the insurer offering a 1 period contract to update the premium from 2,000 to 2500 in period 2 should a hurricane occur in period 1 with probability .04 .

We also wanted to test the robustness of our results by increasing the cost of the multiperiod contract. Insurers might impose a higher loading for a 2-period contract than for a 1period policy because they have to reserve more capital to protect themselves against the risk of not being able to increase premiums in period 2 if a hurricane occurs. We therefore introduced treatment 3 where we added a $5 \%$ loading charge $(\lambda=0.05)$ and treatment 4 where the loading factor was $10 \%(\lambda=0.10)$. These treatments enabled us to test the price sensitivity of the demand for a 2-period policy. Thus in treatments 2, 3 and 4, subjects must decide whether to purchase 1-period insurance, 2-period insurance or decline to buy insurance (see Table 1).

A discussion of the experiment at several workshops with leading research scientists suggested we investigate whether different sequences of hurricanes during the 30 games had an impact on the results. The instructions to the participants indicated that the games were independent, so the results should be similar if one varied the sequence of losses. For this reason we generated two sets of random numbers to determine the sequence of disasters. These two sequences were randomly generated before subjects started playing the game so that we could compare insurance behavior for participants who experienced the first sequence of disasters with insurance behavior for those experiencing the second sequence.

Treatments $1 *, 2 *, 3^{*}$, and $4 *$ were identical to treatments $1,2,3$ and 4, respectively, except for the hurricane sequence. In treatments 1-to-4 two hurricanes occur in game 5, period 1; game 10 , period 2 with a third hurricane occurring in game 21 , period 1 . In treatments $1^{*}$ to $4^{*}$, the first hurricane occurs in game 19, period 1 with a second hurricane occurring in game 28, period 1 The experiment thus consisted of eight conditions with each participant randomly assigned to one of them.

Table 1 summarizes the insurance premiums for each of these conditions. 
Table 1. Period 1 and Period 2 Insurance Premiums for Different Treatments

(1-Period and 2-Period Contracts) (in talers)

\begin{tabular}{|c|c|c|c|c|}
\hline & & Period 1 & $\begin{array}{c}\text { Period } 2 \\
\text { (with no hurricane in period 1) }\end{array}$ & $\begin{array}{c}\text { Period 2 } \\
\text { (with a hurricane in period 1) }\end{array}$ \\
\hline $\begin{array}{l}\text { Treatments } 1 \text { and } 1 * \\
\text { Menu: actuarially-fairly-priced } \\
\text { 1-period contracts only }\end{array}$ & 1-period & 2,000 & 2,000 & 2,500 \\
\hline \multirow{2}{*}{$\begin{array}{l}\text { Treatments } 2 \text { and } 2 * \\
\text { Menu: actuarially-fairly-priced } \\
\text { 1-period and 2-period contracts }\end{array}$} & 1-period & 2,000 & 2,000 & 2,500 \\
\hline & 2-period & 2,010 & 2010 & 2010 \\
\hline \multirow{2}{*}{$\begin{array}{l}\text { Treatments } 3 \text { and } 3 * \\
\text { Menu: actuarially-fairly-priced } \\
\text { 1-period contracts and 5\%-loaded } \\
\text { 2-period contracts }\end{array}$} & 1-period & 2,000 & 2,000 & 2,500 \\
\hline & 2-period & 2,110 & 2110 & 2110 \\
\hline \multirow{2}{*}{$\begin{array}{l}\text { Treatments } 4 \text { and } 4^{*} \\
\text { Menu: actuarially-fairly-priced } \\
\text { 1-period contracts and } 10 \% \text { - } \\
\text { loaded 2-period contracts }\end{array}$} & 1-period & 2,000 & 2,000 & 2,500 \\
\hline & 2-period & 2,210 & 2,210 & 2,210 \\
\hline
\end{tabular}

\subsection{Participants, Selection of the Winners and Payment of Subjects}

The experiment was conducted on a web-based platform with adult subjects from a larger sample of individuals in the United States assembled by the University of Pennsylvania's research community. Our final sample consisted of 445 responses. ${ }^{5}$ Our analysis for treatments $1,2,3$, and 4 had $91,51,42$ and 45 valid responses, respectively. Treatments $1^{*}, 2^{*}, 3^{*}$, and $4^{*}$, had 93, 38, 36 and 49 valid responses, respectively.

We were also interested in the role that attitudes toward risk played on the decision as to whether to purchase insurance coverage and the preference for 1-period or 2-period contracts for those who decided to buy a policy. To measure their degree of risk aversion or risk taking, we asked participants at the end of the experiment to make choices between ten paired lotteries following the now widely used methodology developed by Holt and Laury (2002) (see Section 4.2). We also asked a series of demographic questions (i.e., gender age, education, income and

\footnotetext{
${ }^{5}$ Before a subject began the 30 games, s/he was asked a series of four questions to make sure that s/he understood the impact of a specific insurance decision on the asset level at the end of periods 1 and 2. Subjects who did not answer a question correctly were directed to read the instructions again. Subjects who gave wrong answers to three or four of these tests in a row were not asked to answer the questionnaire, a procedure that is aligned with the recommendation of Oppenheimer, Meyvis, and Davidenko (2009) as a way of increasing the statistical power and reliability of the data set (See Appendix 3 for the test questions.)
} 
employment status). See Appendix 1 Table 6a for a summary of the distributions of these socioeconomic variables. All subjects received a participation fee of $\$ 5$ for taking part in the experiment. The experiment took on average about 30 minutes to complete.

Recent literature has shown the importance of playing for large amounts of money to assure that subjects take the experiment seriously. Subjects in this experiment knew that after the experiment was completed, 1 out of every 100 participants would be randomly selected for a payoff based on one of the 30 games s/he played. This random problem-selection mechanism provides incentives for respondents to play each game for a large amount of real money as if it were the one selected. ${ }^{6}$

So that participants would know the winners would be selected truly randomly, we utilized an external source---the Pennsylvania lottery. Each person was assigned a unique number from 00 to 99 and a letter (A, B, C, D, E). For example, subject number 234 would be assigned the letter $\mathrm{C}$ (third series of 100 participants) and the number 34 . For each series $\mathrm{A}, \mathrm{B}$, C, D, E of 100 participants, we utilized the result of a pre-defined game of the Pennsylvania Lottery: the "Daily Number" game (see http://www.palottery.state.pa.us/Games/Daily-Number for more details of the game) using the first two digits of the winning number of the evening drawing to determine the five participants who would receive the final balance from one of the 30 games they played. We also used the website of the Pennsylvania Lottery to select the winning game. "Treasure Hunt" has five games from A to E and, for each, draws a number from the range $[1,30]$.

All participants were told that the lottery drawing would occur two weeks after the experiment ended and each was sent a personal e-mail telling them the actual date. An Internet link to these lottery results was made available to all participants so the selection of the winners and games was transparent. The five winners were paid the value of their virtual bank account at the end of period 2 for the selected game in addition to their $\$ 5$ participation fee. Given the conversion rate of 1,000 talers $=\$ 5$, a person who decided not to purchase any insurance in the selected game and had not suffered a loss from a hurricane in that game would receive $\$ 525$ (more than 100 times the participation fee).

\footnotetext{
${ }^{6}$ We recognize that it is difficult to completely overcome incentive effects in experiments when a single game and one subject is selected for an actual payoff resulting from his or her choices. For more discussion on these challenges see Holt (1986) and Camerer and Hogarth (1999).
} 


\section{Predictions and Related Literature}

The experiment was designed to test two main hypotheses regarding the purchase of insurance that are supported by theoretical and empirical research.

Hypothesis 1. (H1) There will be a significant number of subjects who will not purchase insurance in any of the treatments.

Several studies reveal a dichotomy in insurance behaviors with respect to low probability events. Some people dismiss the risk and don't want to pay anything for insurance while others worry a lot and are willing to pay much more than the actuarial price for that coverage (Coursey, Hovis, and Schulze, 1987; McClelland, Schulze, and Coursey,. 1993; Ganderton et al., 2000; Laury, McInnes, and Swarthout, 2009). The lack of interest in insurance is consistent with the fact that some people tend to ignore risks whose subjective odds fall below their threshold level of concern. In controlled laboratory insurance experiments for low-probability events, many individuals bid zero for coverage, apparently viewing the probability of a loss as sufficiently small that they were not interested in protecting themselves against it (Slovic et al. 1977; McClelland, Schulze, and Coursey, 1993; Schade, Kunreuther, and Koellinger, 2012). Several empirical studies also reveal that the demand for insurance against low probability high consequence events, such as natural disasters, is typically fairly low (Kunreuther, 1996; Botzen and van den Bergh, 2012; Kousky and Cooke, 2012) even when premiums are highly subsidized as is the case for flood insurance in the U.S. (Browne and Hoyt, 2000; Michel-Kerjan, Lemoynes de Forges, and Kunreuther, 2012; City of New York, 2013; Kunreuther, Meyer, and MichelKerjan,2013). ${ }^{7}$

Similarly, many homeowners residing in communities that are potential sites for nuclear waste facilities have a tendency to dismiss the risk as negligible (Oberholzer-Gee, 1998). One reason for this behavior is that individuals assume that "It won't happen to me" - a form of probability neglect (Tversky and Shafir. 1992; Kunreuther, Novemsky, and Kahneman, 2001; Sunstein, 2002). Since the probability of losses from a hurricane in our experiment is 4 or $5 \%$, it is likely that this heuristic would be utilized by some of the responders.

\footnotetext{
${ }^{7}$ A RAND report estimated that roughly half of properties in 100-year floodplain purchased flood insurance, although there was substantial regional variation (Dixon et al., 2006). As a specific example, only 40 percent of the residents in Orleans Parish had flood insurance when hurricane Katrina hit in 2005 (Bayot, 2005).
} 
Another important bias that would lead some of the respondents not to purchase insurance in any treatment is the tendency for affective forecasts to be subject to what Loewenstein, O'Donoghue, and Rabin (2003) term the projection bias - a tendency to anchor beliefs about how we will feel in the future on what is being felt in the present. Because insurance purchase decisions are normally made prior to a disaster when individuals may not focus on the consequences of suffering a loss, the projection bias predicts a tendency for some decision makers to undervalue insurance.

Another reason why some people may not purchase disaster insurance has to do with the perception that if they are victims of a disaster, many others around them will likely suffer a similar fate. If individuals are concerned not only with their absolute wealth but also their wealth relative to their peers, the correlation of risks from a disaster may lower some homeowners' demand for disaster insurance (Fehr and Schmidt, 2006; Friedl, Lima de Miranda and Schmidt, 2014). While this experiment does not test this theory directly since the subjects are making their decision in isolation, it may be a rationale for Hypothesis 1 if there is a perception by participants that others may also suffer a loss from a hurricane when they do.

Hypothesis 2. (H2) There will be a significant demand for the 2-period contract even when its cost is higher than the actuarially fair premiums, demonstrating the existence of a strong demand for these contracts and an interest in paying a higher price for premium stability.

Based on expected utility theory, an individual who is risk-averse prefers a known and certain amount of wealth to a risky situation that yields the same expected wealth. Jaffee, Kunreuther, and Michel-Kerjan (2010) show theoretically that a risk-averse subject who maximizes expected utility always prefers a fixed price 2-period insurance contract over a variable price 1-period policy when premiums are actuarially fair. Even when 2-period policies have a loading factor while 1-period policies are actuarially fair, Kleindorfer, Kunreuther, and Ou-Yang. (2012) in this journal have shown theoretically that those who are highly risk averse should still prefer a fixed price 2-period contract over a 1-period policy where the premiums can increase significantly in period 2. Empirical findings by Hendel and Lizzeri (2003) discussed in the Introduction in the context of demand for term life insurance also reveal a preference for higher fixed priced multi-year period contracts, implying an interest by consumers in premium stability with respect to life insurance.

Benartzi and Thaler (1999) show experimentally that individuals decline multiple plays of a given gamble due to myopic loss aversion. However, when they are provided with the 
resulting distribution of outcomes they will tend to play the gamble multiple times. In the context of this experiment, individuals are provided with information on the likelihood of a hurricane occurring in periods 1 and 2 and the impact the disaster in period 1 will have on the price of insurance in the following period. Given that they are presented with information on the distribution of premiums over the two periods, we would expect most individuals to purchase a 2-period policy where the premiums are stable over time.

The goal-based model of choice proposed by Krantz and Kunreuther (2007) may provide additional insights as to why individuals may prefer a 2-period insurance policy even when it is priced at $5 \%$ or $10 \%$ above the actuarially fair premium. Suppose some individuals have a goal of spending only a limited amount on insurance against hurricane damage to their house over the two periods. The introduction of a 2-period policy with constant premiums may lead them to purchase insurance that fits into their insurance budget goal rather than purchasing 1-period policies, knowing that in the next period the price of coverage may increase so that their budget constraint would be exceeded.

There is also a literature on how the period of commitment can impact on behavior. Prospect theory (Tversky and Kahneman, 1992; Thaler, 1999; Langer and Weber, 2001) applied to insurance decisions predicts that individuals are more willing to take risk (i.e. not purchase insurance) when they have short time horizons: the perceived expected benefits of not paying premiums to save money dominates the expected costs should a uninsured loss occur because of the perceived low likelihood of a disaster occur. Increasing the time horizon of the decision maker tends to lead individuals to want insurance because of the likelihood of at least one disaster over a multi-year period looms sufficiently high so individuals want to protect themselves and their families. Langer and Weber (2005) show that a longer commitment period tends to decrease risk taking in the context of investment in risky assets where there is a low probability of relatively high losses. Papon (2008) demonstrates that insurance demand in the context of low-probability high-impact events may depend on the length of time individuals commit themselves to maintaining an insurance policy.

Introducing a 2-period contract that cannot be canceled in the menu of options, as we do here, should make the concept of commitment salient to some participants. These individuals are likely to purchase insurance for both periods but may have remained uninsured if their only option was to purchase a 1-period policy. Our experiment complements the work of Papon (2008) in that the multi-period contract not only covers potential losses from a disaster in both periods but also provides price stability by hedging against a possible price increase of a one- 
period insurance contract in period 2 if the external experts estimate the probability of a hurricane in period 2 to be higher than it was in period 1, thus providing price stability.

A mental accounting argument would also lead to a similar prediction should individuals divide their spending into budget categories. As Thaler (1999) points out, the budgeting process can facilitate making tradeoffs between competing uses of funds and acts as a self-control device. Heath and Soll (1996) divide the process by which such budgeting takes place into two stages: expenses must first be noticed and then assigned to their proper accounts. In this experiment, participants know that the insurance premium can increase significantly in period 2 if there is a hurricane in period 1. If they assume they will want to keep insurance in period 2 if they purchase coverage in period 1, they may prefer a 2-period policy over a 1-period policy because it meets their insurance budget constraint.

Finally, some people may feel that the 2-period policy is a bargain if they focus on the higher price they will have to pay to purchase single-period insurance coverage in period 2 should a hurricane occur in period 1. When two types of policies are on the market, some may prefer stable premiums over time and thus purchase a 2-period policy.

A number of empirical studies have also demonstrated that people's preferences between two options can depend on the presence, or absence, of a third alternative (Huber, Payne and Puto 1982; Simonson and Tversky, 1992; Heath and Chatterjee, 1995). The introduction of a 2-period insurance policy into the menu of options may suggest to some individuals that purchasing insurance rather than being uninsured is more desirable since there are now two insurance options for them to consider. As noted by Hutchinson, Kamakura and Lynch (2000), there may be unobserved heterogeneity in people's preferences in treatment 1 which emerge when both 1- and 2-period policies are offered to participants.

\section{Results and Discussion}

\subsection{Descriptive Analyses}

Subjects had the following five alternatives to choose from in each game (except for treatments 1 and $1 *$ where a 2-period insurance contract was not offered):

Alternative 1: No insurance in both periods, which we note $(0,0)$

Alternative 2: No insurance in period 1 but 1-period insurance in period 2, noted $(0,1)$

Alternative 3: 1-period insurance in both periods 1 and 2, noted $(1,1)$

Alternative 4: 1-period insurance in period 1 and no insurance in period 2, noted $(1,0)$ 
Alternative 5: 2-period insurance policy $(2,2)$

Table 2 specifies the percentage of individuals who chose each of the five alternatives in each of the treatments across the 30 games. For each treatment we combine the two scenarios that are identical except for the sequence of hurricanes (that is 1 and $1 * ; 2$ and $2 * ; 3$ and $3 * ; 4$ and $4 *)$.

We find that the vast majority of the subjects decide to buy either no insurance (Alternative 1), two 1-period policies (Alternative 3) or a 2-period policy (Alternative 5) across the different treatments. The data on Alternative 1 reveal that a significant percentage of the subjects did not purchase insurance in both periods for all of the treatments, thus providing confirming evidence for $\mathbf{H 1}{ }^{8}$ Note also that the introduction of another option (a 2-period contract) in the menu of alternatives decreases the proportion of uninsured subjects.

Table 2. Percentage of Individuals Choosing Different Alternatives across the Four Treatments

\begin{tabular}{|l|c|c|c|c|c|}
\hline \multicolumn{1}{|c|}{ Treatments } & $\begin{array}{c}\text { Alternative 1 } \\
\mathbf{( 0 , 0 )}\end{array}$ & $\begin{array}{c}\text { Alternative 2 } \\
\mathbf{( 0 , 1 )}\end{array}$ & $\begin{array}{c}\text { Alternative 3 } \\
\mathbf{( 1 , 1 )}\end{array}$ & $\begin{array}{c}\text { Alternative 4 } \\
\mathbf{( 1 , 0 )}\end{array}$ & $\begin{array}{c}\text { Alternative 5 } \\
\mathbf{( 2 , 2 )}\end{array}$ \\
\hline $\begin{array}{l}\text { 1 and 1* } \\
\text { Menu: no insurance;1-period contract }\end{array}$ & $32.07 \%$ & $6.27 \%$ & $54.09 \%$ & $7.57 \%$ & Not Available \\
\hline $\begin{array}{l}\text { 2 and 2* } \\
\text { Menu: no insurance;1-period contract; } \\
\text { actuarially-fair 2-period contract }\end{array}$ & $27.38 \%$ & $3.86 \%$ & $6.52 \%$ & $4.42 \%$ & $57.82 \%$ \\
\hline $\begin{array}{l}\text { 3 and 3* } \\
\text { Menu: no insurance;1-period contract; } \\
\text { 5\%-load 2-period contract }\end{array}$ & $23.42 \%$ & $3.68 \%$ & $22.98 \%$ & $5.43 \%$ & $44.49 \%$ \\
\hline $\begin{array}{l}\mathbf{4} \text { and 4* } \\
\text { Menu: no insurance;1-period contract; } \\
\text { 10\%-load 2-period contract }\end{array}$ & $25.78 \%$ & $5.00 \%$ & $23.62 \%$ & $5.92 \%$ & $39.68 \%$ \\
\hline
\end{tabular}

Figure 2 compares the demand for both types of insurance contracts under different pricing arrangements across the three treatments where a 2-period contract is included in the menu offered to the subjects. The demand for one-period contracts is defined as: $(1,1)+$ $[(1,0)+(0,1) / 2]$ given that the subjects selecting $(1,0)$ and $(0,1)$ are insured only half of the time.

We find that more than five times as many individuals purchased 2-period insurance than 1-period contracts when both types of contracts are actuarially fair (treatments 2 and $2^{*}$ ).

\footnotetext{
${ }^{8}$ In addition, some of the subjects purchased insurance for only one period (Alternatives 2 and 4 ) and were thus uninsured for half of the game. The percentage of subjects in this category ranged from $8.3 \%$ (Treatment $2 / 2 *$ ) to $13.8 \%$ (Treatment $1 / 1 *)$.
} 
Even when the 2-period contract is priced at 5\% and $10 \%$ above the actuarially fair rate, Figure 2 reveals that a large proportion of the subject pool still prefers 2-period to 1-period policies (44.5\% versus $27.5 \%$ and $39.7 \%$ versus $29.1 \%$, respectively). These data provide support for H2: many individuals like 2-period policies either because they are risk averse, like stability and/or they have other goals influencing their choices such as meeting budget constraints even when the 2-period contract is priced $10 \%$ higher than its actuarially fair price (Treatments 4 and $\left.4^{*}\right)$.

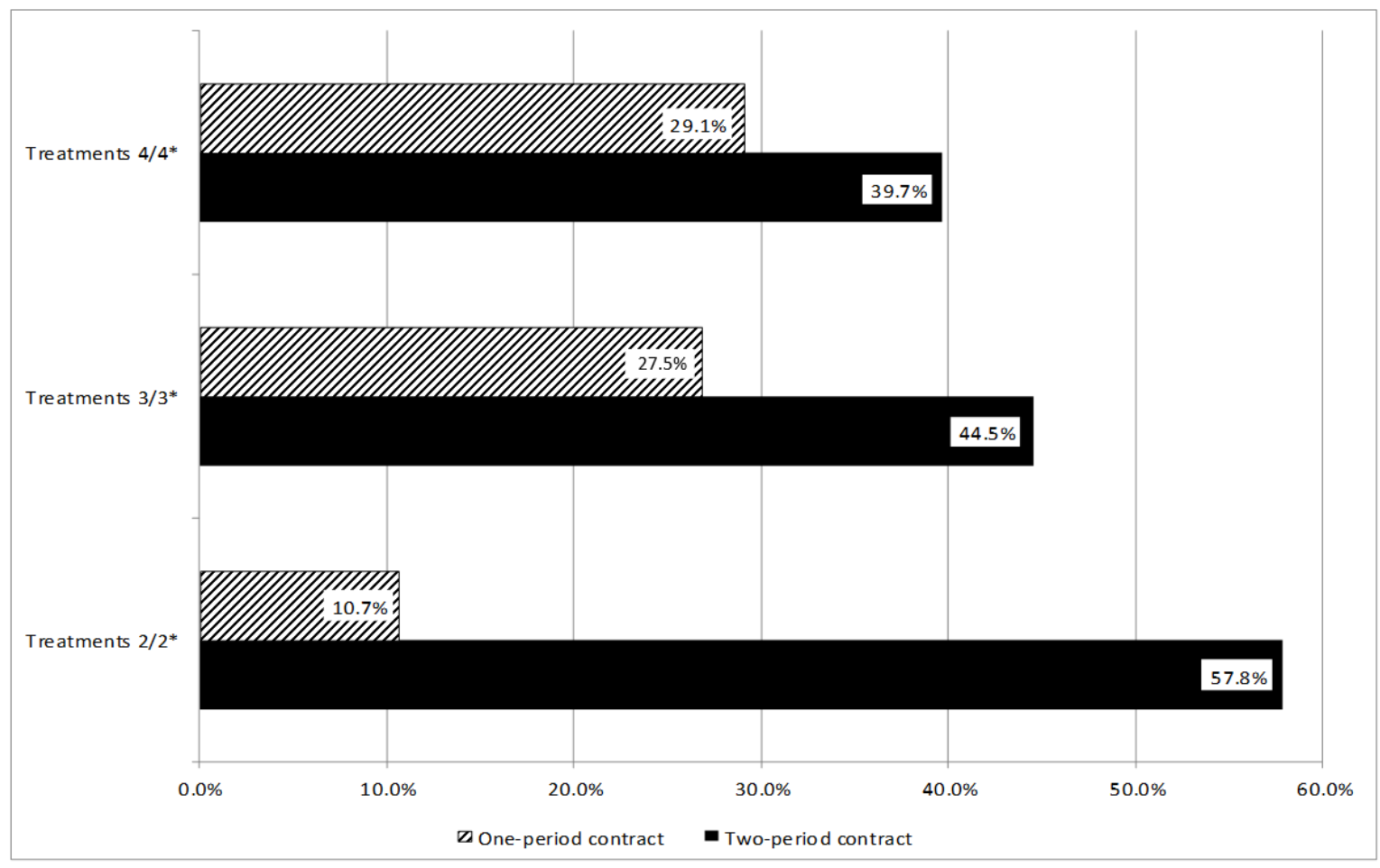

Fig. 2 Demand for 1- and 2-period insurance contracts under different pricing arrangements

\subsection{Multinomial Logit Regression Analysis}

To examine the impact of specific variables on the demand for insurance and the preference between 1- and 2-period contracts we undertook a series of multinomial logit regression analyses. The dependent variables were characterized by the decision alternatives facing a subject in each game with Alternative 1 (Not Purchasing Insurance) as the baseline condition. Given the small number of individuals who chose to purchase insurance for only one of the two periods, we exclude Alternatives 2 and 4 in the discussion of the findings presented below. 
The Holt-Laury (2002) paired lotteries, depicted in Table 3, enable us to determine the impact of risk aversion on the insurance purchase decision. The range of payoffs for Option A $(\$ 1.60 ; \$ 2)$ is smaller than in Option B $(\$ 0.1 ; \$ 3.85)$. As shown in Table 3, (last column), the expected payoff of Option A decreases relative to Option B as one considers higher-numbered paired lotteries. The more risk averse a person is, the more Option A lotteries would be preferred before switching to Option B. The risk attitude (RA) of an individual is determined by the number of times s/he chose Option A in the 10 paired lotteries. A risk neutral person would choose Option A four times before switching to Option B. ${ }^{9}$

Table 3. The Holt-Laury Ten Paired Lottery-Choice Decisions

\begin{tabular}{|c|r|r|}
\hline Option $\mathbf{A}$ & Option B & $\begin{array}{c}\text { Expected payoff } \\
\text { difference }\end{array}$ \\
\hline $1 / 10$ of $\$ 2.00,9 / 10$ of $\$ 1.60$ & $1 / 10$ of $\$ 3.85,9 / 10$ of $\$ 0.10$ & $\$ 1.17$ \\
$2 / 10$ of $\$ 2.00,8 / 10$ of $\$ 1.60$ & $2 / 10$ of $\$ 3.85,8 / 10$ of $\$ 0.10$ & $\$ 0.83$ \\
$3 / 10$ of $\$ 2.00,7 / 10$ of $\$ 1.60$ & $3 / 10$ of $\$ 3.85,7 / 10$ of $\$ 0.10$ & $\$ 0.50$ \\
$4 / 10$ of $\$ 2.00,6 / 10$ of $\$ 1.60$ & $4 / 10$ of $\$ 3.85,6 / 10$ of $\$ 0.10$ & $-\$ 0.18$ \\
$5 / 10$ of $\$ 2.00,5 / 10$ of $\$ 1.60$ & $5 / 10$ of $\$ 3.85,5 / 10$ of $\$ 0.10$ & $-\$ 0.51$ \\
$6 / 10$ of $\$ 2.00,4 / 10$ of $\$ 1.60$ & $6 / 10$ of $\$ 3.85,4 / 10$ of $\$ 0.10$ & $-\$ 0.85$ \\
$7 / 10$ of $\$ 2.00,3 / 10$ of $\$ 1.60$ & $7 / 10$ of $\$ 3.85,3 / 10$ of $\$ 0.10$ & $-\$ 1.18$ \\
$8 / 10$ of $\$ 2.00,2 / 10$ of $\$ 1.60$ & $8 / 10$ of $\$ 3.85,2 / 10$ of $\$ 0.10$ & $-\$ 1.52$ \\
$9 / 10$ of $\$ 2.00,1 / 10$ of $\$ 1.60$ & $9 / 10$ of $\$ 3.85,1 / 10$ of $\$ 0.10$ & $-\$ 1.85$ \\
$10 / 10$ of $\$ 2.00,0 / 10$ of $\$ 1.60$ & $10 / 10$ of $\$ 3.85,0 / 10$ of $\$ 0.10$ & \\
\hline
\end{tabular}

We examined the relative importance of RA, several other demographic variables (e.g., Age, Gender, Education, Income) and the impact of additional premiums of 5\% (PriceAddon5) and 10\% (PriceAddon10) specified by treatments 4 and 5 in predicting the likelihood of 1-period and 2-period insurance policies.

As discussed earlier in the paper we also wanted to analyze whether the sequence of hurricanes affected the insurance purchase decisions by individuals. We thus compared demand for the four treatments under the first sequence of hurricanes (where hurricanes occurred in

\footnotetext{
${ }^{9}$ We used these hypothetical lotteries to determine the degree of risk aversion. Had there been real payoffs for these lotteries and/or the amounts at stake been somewhat higher than those in Table 3, the degree of risk aversion would likely be greater than those we obtained in this experiment as shown by experiments conducted by Harrison et al. (2005) and Holt and Laury (2005). See Harrison and Rutstrom (2008) for a detailed survey on the experimental evidence of risk aversion in controlled laboratory settings.
} 
earlier games $(5,10$, and 21); first sequence, noted FS) with insurance demand under the second sequence where hurricanes occurred in later periods (i.e. during games 19 and 28).

The results of these multinomial logit regressions are presented in Table $4 .{ }^{10}$ As mentioned above, Alternative 1 (uninsured) is the baseline variable from which to judge the likelihood that an individual will want to purchase 1-period or 2-period policies. FS is a dummy variable that is 1 for the first sequence of hurricanes and 0 for the second sequence. As discussed earlier, given that the subjects knew they were playing 30 independent games we did not expect the sequence of disasters to have an impact on the insurance purchase decision.

The multinomial logit regressions on which Table 4 is based were undertaken by assuming that the subject-periods decisions were uncorrelated. ${ }^{11}$ The positive and statistically significant coefficients for RA for Alternatives 3 and 5 indicate that as an individual becomes more risk-averse $\mathrm{s} / \mathrm{he}$ is more likely to purchase insurance. As the price of a 2-period policy becomes more expensive due to the $5 \%$ and $10 \%$ loading factor, the likelihood of an individual purchasing a 1-period policy increases. With respect to the socio-economic variables, those with higher incomes were less likely to buy coverage, presumably because they feel they are more financially able to afford a loss than their lower income counterparts in the experiment.

We are also interested in whether the overall demand for insurance significantly increases after a hurricane occurs, as revealed by empirical evidence in the aftermath of disasters. The literature on learning from past experience is ambivalent in this regard. On the one hand, the availability heuristic implies that people predict the frequency of an event based on how easily an example can be brought to mind (Tversky and Kahneman, 1974), implying that there should be increased interest in purchasing insurance after suffering a loss. On the other hand, empirical research in the laboratory and in casinos indicates some individuals' behaviors are consistent with the gambler's fallacy (Croson and Sundali, 2005), implying that after a disaster individuals will view the likelihood of it occurring in the next period to be much

\footnotetext{
${ }^{10}$ Marginal effects are not reported here but are available from the authors upon request.

${ }^{11}$ We recognize that even though the games were independent there might be some intra-dependence within games played by each individual. We thus calculated the intra-class correlation coefficient and used the coefficient to alter the standard errors of the variables. The results are presented in Table $6 \mathrm{~b}$ of Appendix 1.
} 
lower than the stated probability. Those who exhibit this bias will be less likely to purchase insurance in the next game than if the hurricane had not occurred. ${ }^{12}$

\footnotetext{
${ }^{12}$ Findings from the disaster literature indicate that the demand for insurance often increases immediately after a catastrophe occurs. Michel-Kerjan (2010) shows that the demand for flood insurance in the United States increased by more than 15 percent in 2006, the year following Hurricane Katrina. Similar behavior occurred in California following the 1971 San Fernando earthquake (Sullivan, Mustart and Galehouse,. 1977) and quakes in the early 1980s (Palm et al., 1990). Based on U.S. state-level data for the period 1994 through 2004, Fier and Carson (2010) also show a significant relationship between the occurrence of catastrophes and increased demand for life insurance.
} 
Table 4. Multinomial Logit Regression for Determining Insurance Purchase Choices

\begin{tabular}{|c|c|c|c|}
\hline Coefficient & Estimate & t-value & $\operatorname{Pr}(>|t|)$ \\
\hline 2:(intercept) & $-1.20 *(0.53)$ & -2.29 & 0.02 \\
\hline 3:(intercept) & $-1.39 * * *(0.35)$ & -3.96 & 0.00 \\
\hline 4:(intercept) & $0.20(0.70)$ & 0.28 & 0.78 \\
\hline 5:(intercept) & $0.83 * *(0.27)$ & 3.14 & 0.00 \\
\hline 2:PriceAddon5 & $0.15(0.16)$ & 0.93 & 0.35 \\
\hline 3:PriceAddon5 & $1.51 * * *(0.11)$ & 14.28 & 0.00 \\
\hline 4:PriceAddon5 & $0.41 * *(0.14)$ & 2.91 & 0.00 \\
\hline 5:PriceAddon5 & $-0.03(0.07)$ & -0.44 & 0.66 \\
\hline 2:PriceAddon 10 & $0.47 * * *(0.14)$ & 3.31 & 0.00 \\
\hline 3:PriceAddon 10 & $1.56 * * *(0.10)$ & 15.22 & 0.00 \\
\hline 4:PriceAddon 10 & $0.50 * * *(0.14)$ & 3.73 & 0.00 \\
\hline 5:PriceAddon 10 & $-0.15^{*}(0.07)$ & -2.14 & 0.03 \\
\hline $2: \mathrm{RA}$ & $0.06^{* *}(0.02)$ & 2.75 & 0.01 \\
\hline $3: \mathrm{RA}$ & $0.08 * * *(0.01)$ & 6.35 & 0.00 \\
\hline $4: \mathrm{RA}$ & $0.00(0.02)$ & 0.06 & 0.95 \\
\hline $5: \mathrm{RA}$ & $0.14 * * *(0.01)$ & 12.80 & 0.00 \\
\hline 2:Age & $-0.01(0.01)$ & -1.00 & 0.32 \\
\hline 3:Age & $0.01 *(0.00)$ & 2.52 & 0.01 \\
\hline 4:Age & $-0.03 * * *(0.01)$ & -5.88 & 0.00 \\
\hline 5:Age & $0.01 * * *(0.00)$ & 5.51 & 0.00 \\
\hline 2:Educ & $-0.02(0.07)$ & -0.32 & 0.75 \\
\hline 3:Educ & $0.01(0.04)$ & 0.15 & 0.88 \\
\hline 4:Educ & $-0.34 * * *(0.06)$ & -5.55 & 0.00 \\
\hline $5:$ Educ & $-0.02(0.03)$ & -0.71 & 0.48 \\
\hline 2:Income & $-0.12 * *(0.04)$ & -3.16 & 0.00 \\
\hline 3:Income & $-0.31 * * *(0.03)$ & -12.34 & 0.00 \\
\hline $4:$ Income & $-0.18 * * *(0.04)$ & -4.89 & 0.00 \\
\hline 5:Income & $-0.18 * * *(0.02)$ & -9.61 & 0.00 \\
\hline $2: F S$ & $0.57^{* * *}(0.12)$ & 4.66 & 0.00 \\
\hline $3: F S$ & $0.60 * * *(0.07)$ & 8.18 & 0.00 \\
\hline $4: F S$ & $0.19(0.11)$ & 1.68 & 0.09 \\
\hline $5: F S$ & $0.35 * * *(0.06)$ & 5.98 & 0.00 \\
\hline
\end{tabular}

Since the 30 games are independent from each other and the subjects are told that each new game follows the same probability of a disaster in period 1 and 2 as any other game, however, we should not see an impact. We indeed find no clear pattern to support an increase (or decrease) of post-catastrophe insurance demand for either 1-period or 2-period insurance contracts immediately after a disaster. 
On the other hand, the variable FS has a highly significant positive coefficient with respect to Alternative 3 and 5 ( +0.60 and +0.35 , respectively; see Table 4$)$. This implies that when one experiences a disaster in early games, one is more likely to purchase either 1- or 2period coverage for the remaining games than if the hurricanes occur later in the experiment. This finding is consistent with the results of the experiment by Papon (2008) where individuals were much more likely to purchase insurance in later periods if they had previously suffered a loss.

\subsection{Discussion on the Marginal Effects}

We now highlight the relative importance of the different coefficients in our logit regression (Table 4) that were statistically significant for at least one of the alternatives on the probability of an individual purchasing a specific insurance policy under different treatments. To provide an economic interpretation of these marginal effects, we set age at its mean value across all participants. For interval variables (i.e., risk aversion, education, income) the mean was calculated simply by assigning a 1 to the first interval, 2 for the second, etc. and then taking the average. The resulting mean values were: risk aversion: 5.30 (chose Option A between 5 and 6 times); age: 46 years; education: 3.71 (some college or college graduate); and annual income: 3.30 (between $\$ 50,000$ and $\$ 75,000$ ).

Effects of Changes in Premiums for 2-Period Insurance Policy

PriceAddon5 (noted as P5): As shown in Table 5a, the major effect of increasing the price of a 2-period policy by $5 \%$ above actuarial value $(\mathrm{P} 5=1)$ while holding the 1 -period policy at an actuarially fair premium is to decrease the probability of purchasing 2-period insurance from .74 to .64 , and to increase the probability of purchasing two 1-period policies from .04 to .15 or 0.20 (depending in the disaster sequence). 
Table 5a. Impact of 5 Percent Price Increase in 2-Period Policy on Purchase of Insurance

\begin{tabular}{|l|c|c|c|c|c|}
\hline & Prob(Alt1) & Prob(Alt2) & Prob(Alt3) & Prob(Alt4) & Prob(Alt5) \\
\hline P5 $=0$, P10 $=0$ & 0.18 & 0.04 & 0.04 & 0.007 & 0.74 \\
\hline First Disaster Sequence \\
\hline P5 $=1$, P10 $=0$
\end{tabular}

Note: Results are rounded.

PriceAddon10 (noted as P10). A 10\% increase in premiums leads to a larger decrease in 2period policies (Alt5) and a greater increase in 1-period insurance than when the price increases by only $5 \%$ for both types of hurricane scenarios as shown in Table $5 \mathrm{~b}$.

Table 5b. Impact of 10 Percent Price Increase in 2-Period Policy on Purchase of Insurance

\begin{tabular}{|l|c|c|c|c|c|}
\hline & P(Alt1) & P(Alt2) & P(Alt3) & P(Alt4) & P(Alt5) \\
\hline $\begin{array}{c}\text { P5 }=0, \text { P10 } \\
0,\end{array}$ & 0.19 & 0.04 & 0.04 & 0.007 & 0.74 \\
\hline \\
First Disaster Sequence \\
\hline P5 =0, P10 = 1 & 0.12 & 0.07 & 0.21 & 0.009 & 0.60 \\
\hline \begin{tabular}{l} 
Second Disaster Sequence \\
\hline P5=0, P10=1
\end{tabular} 0.17 & 0.05 & 0.17 & 0.010 & 0.60 \\
\hline
\end{tabular}

\section{Effects of Income}

Table 5c examines the impact of income on insurance purchase when the 2-period insurance premium is actuarially fair and the person is subject to the first disaster sequence and all variables (i.e., age, education and risk aversion) are set at their average values. As income increases, the average subject is more likely to be uninsured. As shown in Table $5 \mathrm{c}$ there is a $20 \%$ chance that a person with an income between $\$ 75,000$ and $\$ 100,000$ will not purchase insurance in either period compared to a $15 \%$ chance when the individual has an income between $\$ 25,000$ and $\$ 50,000 . .^{13}$

\footnotetext{
${ }^{13}$ When the premiums for 2-period policies include a $5 \%$ and $10 \%$ loading factor, the results do not significantly change so we only report the case of actuarial prices.
} 
Table 5c: Impact of Income on Insurance Purchase

\begin{tabular}{|c|c|c|c|c|c|}
\hline Income & $\mathrm{P}($ Alt1 $)$ & $\mathrm{P}($ Alt2 $)$ & $\mathrm{P}($ Alt3) & $\mathrm{P}($ Alt4) & $\mathrm{P}($ Alt5) \\
\hline$\$ 75,000-\$ 100,000$ & 0.20 & 0.04 & 0.03 & 0.01 & 0.72 \\
\hline$\$ 50,000-\$ 75,000$ & 0.18 & 0.03 & 0.04 & 0.01 & 0.74 \\
\hline$\$ 25,000-\$ 50,000$ & 0.15 & 0.03 & 0.05 & 0.01 & 0.76 \\
\hline
\end{tabular}

\section{Impact of Risk Aversion}

To examine the impact of risk aversion (RA) on the probability of choosing each of the five alternatives for the two types of hurricane scenarios to which subjects are exposed, three values of RA are selected: $\mathrm{RA}=4$ (risk neutral) and $\mathrm{RA}=6$ (risk averse) and $\mathrm{RA}=8$ (very risk averse). The data in Table $5 \mathrm{~d}$ reveal that individuals who are risk neutral have a 0.80 probability of purchasing insurance when the premiums are actuarially fair [1-Prob(Alt1)]. This probability increases to .83 when subjects are risk averse and to .87 when they are very risk averse and face a scenario where hurricanes occur in the later games $(\mathrm{FS}=0)$. When hurricanes occur early (FS=1) the probability of risk-neutral subjects purchasing some insurance increases to 0.85 . Even when individual are highly risk averse $(\mathrm{RA}=8)$, there is a .10 probability that will not purchase any insurance against disasters, even though it is priced at an actuarially fair rate, presumably because they treat the likelihood of a hurricane as below their threshold level of concern.

As anticipated, the demand for 2-period insurance increases with the degree of risk aversion. The probability of purchasing a 2-period insurance policy (Alt5) increases from .74 for risk neutral individuals to .81 for those who are highly risk averse for the first disaster sequence. There is a similar increase in the likelihood of purchasing a 2-period policy for the second disaster sequence. 
Table 5d: Impact of Risk Aversion on Insurance Purchase

\begin{tabular}{|l|c|c|c|c|c|}
\hline & Prob(Alt1) & Prob(Alt2) & Prob(Alt3) & Prob(Alt4) & Prob(Alt5) \\
\hline \multicolumn{5}{|l|}{ First Disaster Sequence } \\
\hline RA = 8 & 0.10 & 0.04 & 0.05 & 0.00 & 0.81 \\
\hline $\mathrm{RA}=6$ & 0.12 & 0.04 & 0.05 & 0.01 & 0.78 \\
\hline $\mathrm{RA}=4$ & 0.15 & 0.05 & 0.05 & 0.01 & 0.74 \\
\hline \multicolumn{5}{|l|}{} \\
\hline Second Disaster Sequence \\
\hline $\mathrm{RA}=8$ & 0.13 & 0.03 & 0.04 & 0.01 & 0.79 \\
\hline $\mathrm{RA}=6$ & 0.17 & 0.03 & 0.03 & 0.01 & 0.76 \\
\hline $\mathrm{RA}=4$ & 0.20 & 0.04 & 0.04 & 0.01 & 0.71 \\
\hline
\end{tabular}

\section{Conclusions and Implications}

This paper examines demand for fixed-price multi-period contracts to hedge against possible price increases in the future in the context of insurance for low probability high consequence disasters. We undertook a repeated web-based game experiment with adults across the United States with a significant amount of real money at stake. Depending on the treatment, between $23 \%$ and $33 \%$ of the participants do not purchase insurance, confirming a well documented finding in the literature on decision making under risk and uncertainty.

The findings demonstrate a strong demand for fixed-priced multi-period contracts. More than five times as many individuals chose the fixed-price 2-period insurance policy over a 1period contract when prices are actuarially fair. Even when a $10 \%$ loading factor is placed on the 2-period policy, almost $40 \%$ of the subjects purchased a multi-period contract. This implies that a number of participants are willing to pay extra for price stability over time.

A multinomial logit regression analysis revealed that as income increases, the average subject is more likely to be uninsured. Risk aversion is found to increase the demand for 2period insurance: based on their responses to the Holt-Laury (2002) paired lotteries, highly riskaverse individuals are more likely to purchase 2-period rather than 1-period policies. These results are robust to different sequences of disasters occurring across the 30 game experiments; the demand for such multi-period contracts slightly increases when the disasters occurred earlier in the experiment, maybe because individuals were able to appreciate the value of a stable premium rather than having it increase significantly after a disaster had they purchased 1-period policies. 
Future research should examine the demand for proposed extended contracts when we increase the number of periods in a game and offer multi-year insurance (MYI) contracts for three or more periods in addition to the 1- and 2-period policies, varying the probabilities and losses to see how these factors influence the demand for insurance. If commitment is an important element of buying longer term insurance, as suggested by Papon (2008), then we would expect that the demand for those longer contracts might actually be even higher as would the overall demand for insurance.

There might be an optimal length that balances the desire for premium stability with the ability to cancel a contract after several years. One could also allow subjects to cancel their multi-period policy at a pre-specified cost before the contract ends in a manner similar to the refinancing of mortgages when interest rates decline. The experiments could also be undertaken in other countries so we account for possible cultural differences with respect to demand for insurance.

A limitation of this experiment is that individuals do not actually purchase insurance nor do they have to live through the trauma of losing their assets from a disaster. We partially addressed this point by having adults with personal experience in purchasing insurance as participants in the experiment rather than college students and by increasing the amount of money at stake. Pilot field experiments could examine the actual demand for annual or multiyear policies on specific risks when policyholders have that option. These studies would be conducted in collaboration with insurers to measure the interest of their clients in purchasing the proposed multi-year contracts and the sensitivity of demand to contract design and to the socio-economic characteristics of the clients.

Our findings suggest that there may be untapped opportunities to increase the demand for catastrophe coverage by offering multi-year contracts in addition to the traditional annual policies offered today. Insurers can deal with correlated risks from a disaster by diversifying their portfolio by utilizing catastrophe models so they do not have a large number of policies in one geographic area. An advantage of an MYI policy is that it spreads losses over individuals as well as over time, thus reducing variance via the law of large numbers. When designing MYI policies one can always incorporate inflation-adjusted clauses and re-evaluate risks every 3-5 years if one is concerned about correlated losses over time due to environmental changes such as sea level rise from global warming. 
The interest in multi-year contacts has important policy implications as well. For instance, the federally-run National Flood Insurance Program (NFIP) provides a natural candidate for marketing such policies. The catastrophic flood losses from hurricanes in 2004, 2005 and 2008 created a $\$ 17$ billion deficit in the program, an amount that the NFIP had to borrow from the U.S. Treasury to meets its claims obligations and now has to repay. This shortfall in revenue has stimulated considerable discussion and debate as to ways to reform and redesign flood insurance (Michel-Kerjan, 2010; Michel-Kerjan and Kunreuther, 2011). After Hurricane Sandy in 2012, it had to borrow another $\$ 9.7$ billion.

In 2012 and 2014, the U.S. Congress extended the NFIP for several years and required that premiums move to better reflect risk for many existing properties and all new properties within the floodplain over time. As part of the redesign of the program, multi-year flood insurance could be introduced into its current menu of contracts with the policy tied to the structure rather than the homeowner. Should the homeowner move to another location, the flood insurance policy would remain with the property. Multi-year insurance would also ensure the spread of risk within the program and over time, providing much needed financial revenue for the program. 


\section{References}

Benartzi, S., \& Thaler, R. (1999). Risk Aversion or Myopia? Choices in Repeated Gambles and Retirement Investments. Management Science. 45(3): 364-381.

Botzen, W. J. \& van den Bergh, J (2012). Monetary Valuation of Insurance against Flood Risk under Climate Change. International Economic Review. 53: 1005-1026.

Camerer, C., \& Hogarth, R. (1999). The Effects of Financial Incentives in Experiments: A Review of Capital-Labor-Production Framework. Journal of Risk and Uncertainty. 19: 7-42.

Coursey, D., Hovis, J. \& Schulze, W. (1987). The disparity between willingness to accept and willingness to pay measures of value. Quarterly Journal of Economics. 102(3): 679-690.

Croson, R., \& Sundali, J. (2005). The Gambler's Fallacy and the Hot Hand: Empirical Data from Casinos. Journal of Risk and Uncertainty. 30(3): 195-209.

Bayot, J. (2005). "Payouts hinge on the cause of damage. "New York Times, August 31.

Browne, M., \& Hoyt, R. (2000). The Demand for Flood Insurance: Empirical Evidence. Journal of Risk and Uncertainty. 20(3): 291-306.

Dixon, L., Clancy, N., Seabury, S. A., \& Overton, A. (2006). The National Flood Insurance Program's Market Penetration Rate: Estimates and Policy Implications (Santa Monica, CA: RAND Corporation).

Donner, A., Birkett, N., \& Buck, C. (1981). Randomization by Cluster. American Journal of Epidemiology. 114: 906-914.

Fehr, E., \& Schmidt, K. M. (2006). The Economics of Fairness, Reciprocity, and AltruismExperimental Evidence and New Theories. In S. C. Kolm \& J. M. Ythier (Eds.), Handbook of the economics of giving, altruism and reciprocity, vol. 1 (pp. 615-691). North-Holland: Elsevier. 
Fier, S. G., \& Carson, J. (2010). Catastrophes and the Demand for Life Insurance. Florida State University. Available: http://ssrn.com/abstract=1333755

Friedl, A., Lima de Miranda, K., \& Schmidt, U. (2014). Insurance Demand and Social Comparison: An Experimental Analysis. Journal of Risk and Uncertainty, 48(2): 97-109.

Ganderton, P. T., Brookshire, D. S., McKee, M., Steward, S., \& Thurston, H. (2000). Buying Insurance for Disaster-Type Risks: Experimental Evidence. Journal of Risk and Uncertainty. 20(3), 271-289.

Grace, M., \& Klein, R. (2009). The Perfect Storm: Hurricanes, Insurance and Regulation. Risk Management and Insurance Review. 12: 81-124.

Harrison, G., Johnson, E., McInnes, M., \& Rutstrom, E. (2005). Risk Aversion and Incentive Effects: Comment. American Economic Review. 95: 897-901.

Harrison, G,. \& Rutstrom, E. (2008). Risk Aversion in Experiments. Research in Experimental Economics. 12: 41-196.

Heath, T., \& Chatterjee, S. (1995). Asymmetric Decoy Effects on Lower-Quality Versus Higher-Quality Brands: Meta-Analytic and Experimental Evidence. Journal of Consumer Research. 22(3): 268-284.

Heath, C., \& Soll, J. (1996). Mental Budgeting and Consumer Decisions. Journal of Consumer Research. 20: $40-52$.

Hendel, I., \& Lizzeri, A. (2003). The Role of Commitment in Dynamic Contracts: Evidence from Life Insurance. Quarterly Journal of Economics. 118(1): 299-327.

Holt, C. (1986). Preference reversals and the independence axiom. American Economic Review. 76: 508515.

Holt, C., \& Laury, S. (2002). Risk Aversion and Incentive Effects. American Economic Review. 92: 1644-1655. 
Holt, C., \& Laury, S. (2005). Risk Aversion and Incentive Effects: Comment. American Economic Review. 95: 902-904.

Huber, J., Payne, J. W., \& Puto, C. (1982). Adding Asymmetrically Dominated Alternatives: Violations of Regularity and the Similarity Hypothesis. Journal of Consumer Research. 9(1): 90-98.

Hutchinson, J, W., Kamakura, W., \& Lynch, J. (2000). Unobserved Heterogeneity as an Alternative Explanation for "Reversal" Effects in Behavioral Research. Journal of Consumer Research. 27: 32444.

Jaffee, D., Kunreuther, H., \& Michel-Kerjan, E. (2010). Long-Term Property Insurance. Journal of Insurance Regulation. 29(07): 167-187.

Kish, L. (1965). Survey Sampling. New York: John Wiley \& Sons.

Klein, R. (2007). Catastrophic Risk and the Regulation of Property Insurance: A Comparative Analysis of Five States" Working Paper, Georgia State University, December.

Kleindorfer, P., Kunreuther, H., \& Ou-Yang, C. (2012). Single-Year and Multi-Year Insurance Policies in a Competitive Market. Journal of Risk and Uncertainty. 45(1): 51-78.

Kousky, C., \& Cooke, R. (2012). Explaining the Failure to Insure Catastrophic Risks. The Geneva Papers. 37: 206-227.

Kousky, C., \& Michel-Kerjan, E. (2012). Hurricane Sandy, Storm Surge, and the National Flood Insurance Program: A Primer on New York and New Jersey. Resources for the Future, Issue Brief 12-08, November 2012. http://www.rff.org/RFF/Documents/RFF-IB-12-08.pdf.

Krantz, D., \& Kunreuther, H. (2007). Goals and Plans in Decision Making. Judgment and Decision Making. 2(3): 137-168. 
Kriesel, W., \& Landry, C. (2004). Participation in the National Flood Insurance Program: An Empirical Analysis for Coastal Properties. Journal of Risk and Insurance. 71(3): 405-420.

Kunreuther, H. (1996). Mitigating disaster losses through insurance. Journal of risk and Uncertainty, 12(2-3), 171-187.

Kunreuther, H., Meyer, R., \& Michel-Kerjan, E. (2013). Overcoming Decision Biases to Reduce Losses from Natural Catastrophes. In E. Shafir (Ed.), Behavioral Foundations of Policy, Princeton University Press.

Kunreuther, H., \& Michel-Kerjan, E. (2011). At War with the Weather: Managing Large-Scale Risks in a New Era of Catastrophes. MIT Press. Paperback edition.

Kunreuther, H., Novemsky, N., \& Kahneman. D. (2001). Making Low Probabilities Useful. Journal of Risk and Uncertainty. 23: 103-120.

Langer, T. \& Weber, M. (2001). Prospect Theory, Mental Accounting, and Differences in Aggregated and Segregated Evaluation of Lottery Portfolios. Management Science. 47: 716-733.

Langer, T \& Weber, M. (2005). Myopic Prospect Theory vs. Myopic Loss Aversion: How General Is the Phenomenon? Journal of Economic Behavior and Organization. 56(1): 25-38.

Laury, S. K., McInnes, M. M., \& Swarthout, J. T. (2009). Insurance decisions for low-probability losses. Journal of Risk and Uncertainty, 39(1), 17-44.

Lecomte, E., \& Gahagan, K. (1998). Hurricane Insurance Protection in Florida. In H. Kunreuther \& R. Roth, Sr. (Eds.) Paying the Price: The Status and Role of Insurance against Natural Disasters in the United States. Washington, D.C.: Joseph Henry Press, 97-124.

Loewenstein, G., O'Donoghue, T., \& Rabin, M. (2003). Projection Bias in Predicting Future Utility. Quarterly Journal of Economics. 118(4): 1209-1248. 
McClelland, G. H., Schulze, W., \& Coursey, D. L. (1993). Insurance for Low Probability Hazards: A Bimodal Response to Unlikely Events. Journal of Risk and Uncertainty. 7: 95-116.

Michel-Kerjan, E. (2010). Catastrophe Economics: The U.S. National Flood Insurance Program. Journal of Economic Perspectives. 24(4): 165-86.

Michel-Kerjan, E., \& Kunreuther, H. (2011). Reforming Flood Insurance. Science. 333: 408-409.

Michel-Kerjan, E., Lemoynes de Forges, S., \& Kunreuther, H. (2012). Policy Tenure under the National Flood Insurance Program. Risk Analysis. 32(4): 644-658.

Mooney, S. (2001). Long-Term Homeowners Policies Make Sense. National Underwriter. February 26, p. 19.

Oberholzer-Gee, F. (1998). Learning to Bear the Unbearable: Towards an Explanation of Risk Ignorance. Mimeo, Wharton School, University of Pennsylvania.

Oppenheimer, D., Meyvis, T., \& Davidenko, N. (2009). Instructional Manipulation Checks: Detecting Satisficing to Increase Statistical Power. Journal of Experimental Social Psychology. 45: 867-872.

Palm, R., Hodgson, M. E.., Blanchard, D., \& Lyons, D. I. (1990). Earthquake Insurance in California. Boulder, CO: Westview.

Papon, T. (2008). The Effect of Pre-commitment and Past-Experience on Insurance Choices: An Experimental Study. Geneva Risk and Insurance Review. 33(1): 47-73.

Schade, C., Kunreuther, H., \& Koellinger, P. (2012). Protecting against Low Probability Disasters: The Role of Worry. Journal of Behavioral Decision Making. 25(5): 534-543.

Simonson, I., \& Tversky, A. (1992). Choice in Context: Tradeoff Contrast and Extremeness Aversion. Journal of Marketing Research. 29(3): 281-295. 
Slovic, P., Fischhoff, B., Lichtenstein, S., Corrigan, B., \& Combs, B. (1977). Preferences for Insuring against Probable Small Losses: Insurance Implications. Journal of Risk and Insurance. 44: 237-258.

Sullivan, R., Mustart, D. A., \& Galehouse, J. S. (1977). Living in Earthquake Country. California Geology. 30(1): 3-8.

Sunstein, C. (2002). Probability Neglect: Emotions, Worst Cases, and Law. Yale Law Journal. 112: 61107.

Thaler, R. (1999). Mental Accounting Matters. Journal of Behavioral Decision Making. 12: 183-206.

Tversky, A., \& Kahneman, D. (1974). Judgments under Uncertainty: Heuristics and Biases. Science. 185: $1124-1131$.

Tversky, A. \& Kahneman, D. (1992). Advances in Prospect Theory: Cumulative Representation of Uncertainty. Journal of Risk and Uncertainty. 5: 297-323.

Tversky, A., \& Shafir, E. (1992). Choice under conflict: The dynamics of deferred decision. Psychological Science. 3(6): 358-361.

U.S. Government Accountability Office. (2007). Natural Disasters: Public Policy Options for Changing the Federal Role in Natural Catastrophe Insurance. Washington, D.C.: GAO-08-7, November

Vitelo, P. (2007). Hurricane Fears Cost Homeowners Coverage. New York Times, October 16. 


\section{Appendix 1:}

Table 6a. Demographics of Participants Selected for the Analysis

\begin{tabular}{|c|c|c|c|c|}
\hline Gender & Age & Education & Income $^{14}$ & Employment \\
\hline $\begin{array}{c}\text { Female } \\
299(67 \%)\end{array}$ & $\begin{array}{c}21-29 \\
30(7 \%)\end{array}$ & $\begin{array}{c}\text { Primary School } \\
1\end{array}$ & $\begin{array}{c}{[\$ 0 ; \$ 25,000]} \\
45(10 \%)\end{array}$ & $\begin{array}{l}\text { Employed } \\
301(68 \%)\end{array}$ \\
\hline \multirow[t]{5}{*}{$\begin{array}{c}\text { Male } \\
146(33 \%)\end{array}$} & $\begin{array}{c}30-39 \\
121(27 \%)\end{array}$ & $\begin{array}{c}\text { High School } \\
54(12 \%)\end{array}$ & $\begin{array}{c}\$ 25,000 ; \$ 50,000] \\
105(24 \%)\end{array}$ & $\begin{array}{c}\text { Retired } \\
57(12 \%)\end{array}$ \\
\hline & $\begin{array}{c}40-49 \\
120(27 \%)\end{array}$ & $\begin{array}{c}\text { Two-year College } \\
107(24 \%)\end{array}$ & $\begin{array}{c}{[\$ 50,000 ; \$ 75,000]} \\
105(24 \%)\end{array}$ & $\begin{array}{l}\text { Student } \\
16(4 \%)\end{array}$ \\
\hline & $\begin{array}{c}50-59 \\
113(25 \%)\end{array}$ & $\begin{array}{c}\text { Undergraduate } \\
\text { Degree } \\
198(44 \%)\end{array}$ & $\begin{array}{c}{[\$ 75,000 ; \$ 100,000]} \\
89(20 \%)\end{array}$ & $\begin{array}{c}\text { Unemployed } \\
71(16 \%)\end{array}$ \\
\hline & $\begin{array}{c}60-69 \\
52(12 \%)\end{array}$ & $\begin{array}{c}\text { Master's or PhD } \\
\text { Degree } \\
85(19 \%)\end{array}$ & $\begin{array}{c}{[\$ 100,000 ; \$ 150,000]} \\
54(12 \%)\end{array}$ & \\
\hline & $\begin{array}{l}70-78 \\
9(2 \%)\end{array}$ & & $\begin{array}{c}>\$ 150,000 \\
17(4 \%)\end{array}$ & \\
\hline
\end{tabular}

$\mathrm{N}=445$

Note: According to the U.S. Census, the median age of the U.S. population in 2010 was 37.2 so our sample is slightly older. The U.S. Census also reports as of 2012 that about $30 \%$ of the population over 25 years has only a high school diploma, 26\% have some college years, $20 \%$ have a college degree, and about $11 \%$ have a Master's or $\mathrm{PhD}$ degree. Our sample is thus slightly more educated than the average American population. As for the income distribution, the distribution across the entire U.S. population is as follows: [\$0; $\$ 25,000]$ : 28\%; [\$25,000; $\$ 50,000]: 26.6 \%$; [\$50,000; \$75,000]: 18.3\%; [\$75,000; \$100,000]: 11\%; [\$100,000; \$150,000]: 10\%; >\$150,000: $6 \%$. Our sample is thus fairly representative of the U.S. population regarding income level. (Sources: U.S. Census 2010 and 2012).

\footnotetext{
1430 responders $(6 \%)$ answered "not applicable."
} 
Table 6b. Multinomial Logit Regression for Determining Insurance Purchase Choices Adjusted by the Intra-class Correlation Coefficient*

\begin{tabular}{|l|r|r|r|}
\hline \multicolumn{1}{|c|}{ Coefficient } & Estimate & Standard Error & Two-tailed p \\
\hline 2:(intercept) & -1.20 & 2.417 & 0.616 \\
\hline 3:(intercept) & -1.39 & 1.596 & 0.385 \\
\hline 4:(intercept) & 0.20 & 3.192 & 0.951 \\
\hline 5:(intercept) & 0.83 & 1.231 & 0.491 \\
\hline 2:PriceAddon5 & 0.15 & 0.730 & 0.838 \\
\hline 3:PriceAddon5 & 1.51 & 0.502 & 0.002 \\
\hline 4:PriceAddon5 & 0.41 & 0.638 & 0.523 \\
\hline 5:PriceAddon5 & -0.03 & 0.319 & 0.923 \\
\hline 2:PriceAddon10 & 0.47 & 0.638 & 0.468 \\
\hline 3:PriceAddon10 & 1.56 & 0.456 & 0.001 \\
\hline 4:PriceAddon10 & 0.50 & 0.638 & 0.413 \\
\hline 5:PriceAddon10 & -0.15 & 0.319 & 0.639 \\
\hline 2:RA & 0.06 & 0.091 & 0.546 \\
\hline 3:RA & 0.08 & 0.046 & 0.164 \\
\hline 4:RA & 0.00 & 0.091 & 0.990 \\
\hline 5:RA & 0.14 & 0.046 & 0.005 \\
\hline 2:Age & -0.01 & 0.046 & 0.826 \\
\hline 3:Age & 0.01 & 0.000 & 0.581 \\
\hline 4:Age & -0.03 & 0.046 & 0.197 \\
\hline 5:Age & 0.01 & 0.000 & 0.227 \\
\hline 2:Educ & -0.02 & 0.319 & 0.944 \\
\hline 3:Educ & 0.01 & 0.182 & 0.974 \\
\hline 4:Educ & -0.34 & 0.274 & 0.224 \\
\hline 5:Educ & -0.02 & 0.137 & 0.876 \\
\hline 2:Income & -0.12 & 0.182 & 0.488 \\
\hline 3:Income & -0.31 & 0.137 & 0.007 \\
\hline 4:Income & -0.18 & 0.182 & 0.284 \\
\hline 5:Income & -0.18 & 0.091 & 0.035 \\
\hline 2:FS & 0.57 & 0.547 & 0.307 \\
\hline 3:FS & 0.60 & 0.319 & 0.073 \\
\hline 4:FS & 0.19 & 0.274 & 0.713 \\
\hline 5:FS & & & 0.190 \\
\hline
\end{tabular}

* Based on the intraclass correlation of 0.684, we calculated the design effect (Kish 1965) or variance inflation factor (Donner, Birkett, and Buck, 1981) to be 20.8, and adjusted our standard errors by a factor of 4.56. Marginal effects are not reported here but are available from the authors upon request. 


\section{Appendix 2:}

\section{Instructions received by the individuals who participated in the experiment}

\section{Instructions for one-period insurance contracts}

Imagine you own a house for two periods and want to sell it at the end of period 2. The house is worth 100,000 talers at the beginning of period 1. A taler is an artificial currency, similar to a dollar in the U.S. or a pound in Great Britain. Your total assets at the beginning of period 1 are the value of your house plus 5,000 talers in cash.

There is a chance that a major hurricane will occur in each period of this two-period game. It is important to note that a hurricane can occur in either period 1 or 2 , or in both periods. If a hurricane occurs in a period, your house will suffer a loss in value of 50,000 talers. You can protect yourself against a loss if you purchase insurance.

If you have purchased insurance and a hurricane occurs, then you will be reimbursed by the insurer for your loss and you will rebuild your house so it has the same value that it had at the beginning of the period.

If you have not purchased insurance and a hurricane occurs, then the value of your house will decrease by 50,000 talers.

The value of your house at the end of each period thus depends on whether a hurricane occurred and whether you bought insurance or not. The total value of your assets at the end of period 2 will be the value of your house at the end of period 2 plus 5,000 talers minus any insurance premiums you paid in any of the two periods.

The chance that a hurricane will occur in period 1 is 1 in 25 (which is a chance of 4\%). If no hurricane occurs in period 1 , the chance of a hurricane in period 2 remains the same ( 1 in 25). If, however, a hurricane occurs in period 1 , the likelihood of a hurricane in period 2 increases to 1 in 20 (which is a chance of $5 \%$ ). The computer will determine the occurrence of a hurricane using a random number generator.

You have the option of purchasing one-period insurance contracts to protect the value of your house against potential losses from hurricanes. The prices of insurance per period are as follows:

2,000 talers in period 1

2,000 talers in period 2 if no hurricane occurred in period 1

2,500 talers in period 2 if a hurricane occurred in period 1

\section{Playing the game}

After you have decided whether or not to buy insurance in period 1, you will see on the computer screen whether a hurricane occurs in that period. You will then have to decide whether to buy insurance in period 2.

Once the first game (two periods) is complete, you will begin a new two-period game with exactly the same rules. You will play 30 such two-period games. 


\section{Instructions for one-period and two-period insurance contracts}

Imagine you own a house for two periods and want to sell it at the end of period 2. The house is worth 100,000 talers at the beginning of period 1. A taler is an artificial currency, similar to a dollar in the U.S. or a pound in Great Britain. Your total assets at the beginning of period 1 are the value of your house plus 5,000 talers in cash.

There is a chance that a major hurricane will occur in each period of this two-period game. It is important to note that a hurricane can occur in either period 1 or 2, or in both periods. If a hurricane occurs in a period, your house will suffer a loss in value of 50,000 talers. You can protect yourself against a loss if you purchase insurance.

If you have purchased insurance and a hurricane occurs, then you will be reimbursed by the insurer for your loss and you will rebuild your house so it has the same value that it had at the beginning of the period.

If you have not purchased insurance and a hurricane occurs, then the value of your house will decrease by 50,000 talers.

The value of your house at the end of each period thus depends on whether a hurricane occurred and whether you bought insurance or not. The total value of your assets at the end of period 2 will be the value of your house at the end of period 2 plus 5,000 talers minus any insurance premiums you paid in any of the two periods.

The chance that a hurricane will occur in period 1 is 1 in 25 (which is a chance of 4\%). If no hurricane occurs in period 1, the chance of a hurricane in period 2 remains the same (1 in 25). If, however, a hurricane occurs in period 1, the likelihood of a hurricane in period 2 increases to 1 in 20 (which is a chance of 5\%). The computer will determine the occurrence of a hurricane using a random number generator.

You have the option of purchasing one-period or two-period insurance contracts to protect the value of your house against potential losses from hurricanes. The prices of insurance per period are as follows:

One-period contracts

2,000 talers in period 1

2,000 talers in period 2 if no hurricane occurred in period 1

2,500 talers in period 2 if a hurricane occurred in period 1

or a

Two-period contract (you purchase insurance for both periods at the beginning of period 1)"

\$XXX talers in period 1 (X could take three values: \$2,010; \$2,110; \$2,210)

\section{Playing the game}

After you have decided whether or not to buy insurance in period 1, you will see on the computer screen whether a hurricane occurs in that period.

If you have purchased a two-period insurance contract, you are automatically protected against a loss in period 2. If you have not purchased insurance, or have purchased a one-period contract in period 1, you will have to decide at the beginning of period 2 whether you want insurance in period 2 .

Once the first game (two periods) is complete, you will begin a new two-period game with exactly the same rules. You will play 30 such two-period games. 


\section{Appendix 3. Test questions}

In order to make sure that the only responses we analyze were made by people who understood the experiment well, we ask all 500 participants to answer 4 test questions before the experiment actually started, as follows:

"We will now ask you some test questions in order to make sure that you understand the instructions correctly.

Feel free at any time during this survey to follow the link that allows you to read the instructions again." (Note that he word instruction had a hyperlink so the participants of this web-based experiment could easily click on it and read the instruction again any time they wanted.

"You might even want to print them out, so you can easily read them again any time you want."

\section{Test Question 1}

"What will happen to the price of a one-period insurance contract in period 2 if a hurricane occurs in period 1 ?

a) The price will remain at 2,000 talers

b) The price will increase to 2,500 talers"

Depending on whether the participant got the right or wrong answer she would see the following on his/her screen.

"Your answer was correct. The price increases to 2,500 talers. The occurrence of a hurricane in period 1 leads insurers to increase the price of insurance in period 2.

If necessary, feel free to read the instructions again."

or

"Your answer was not correct. The correct answer is that the price increases to 2,500 talers. The occurrence of a hurricane in period 1 leads insurers to increase the price of insurance in period 2.

If necessary, feel free to read the instructions again."

\section{Test Question 2}

Imagine you decide to buy a one-period insurance contract in period 1 and a hurricane occurs in period 1 . The total value of your assets at the end of period 1 is:

a) 53,000 talers

b) 103,000 talers

c) 55,000 talers

Depending on whether the participant got the right or wrong answer she would see the following on his/her screen.

"Your answer is correct. 2,000 talers for purchasing insurance equals 103,000. It does not matter whether a hurricane occurs since you will be reimbursed by the insurance company for your loss.

If necessary, feel free to read the instructions again."

or

"Your answer was not correct. The correct answer is 103,000 talers, which is the initial house value 
(100,000 talers) plus 5,000 talers cash minus 2,000 talers for purchasing insurance. It does not matter whether a hurricane occurs since you will be reimbursed by the insurance company for your loss.

If necessary, feel free to read the instructions again."

\section{Test Question 3}

"Imagine you decide not to buy insurance in period 1 and a hurricane occurs in period 1 . The total value of your assets at the end of period 1 is:

a) 53,000 talers

b) 50,000 talers

c) 55,000 talers"

Depending on whether the participant got the right or wrong answer she would see the following on his/her screen.

"Your answer was correct because the initial house value (100,000 talers) plus 5,000 talers cash minus the 50,000 talers loss from the hurricane equals 55,000. You pay nothing for insurance, but you suffer the loss from the hurricane and will not be reimbursed for it.

If necessary, feel free to read the instructions again."

or

"Your answer was not correct. The correct answer is 55,000 talers, which is the initial house value $(100,000$ talers) plus 5,000 talers cash minus the 50,000 talers loss from the hurricane. You pay nothing for insurance, but you suffer the loss from the hurricane and will not be reimbursed for it.

If necessary, feel free to read the instructions again."

\section{Test Question 4}

"What will happen to the price of a two-period insurance contract in period 2 if a hurricane occurs in period 1 ?

a) The price will increase

b) The price will remain the same"

Depending on whether the participant got the right or wrong answer she would see the following on his/her screen.

"Your answer was correct. The price of the two-period insurance contract is fixed for both periods and will not increase in period 2 if a hurricane occurs in period 1."

or

"Your answer was not correct. The correct answer is that the price of the two-period insurance contract is fixed for both periods and will not increase in period 2 if a hurricane occurs in period 1." 